\title{
Norepinephrine Bitartrate
}

National Cancer Institute

\section{Source}

National Cancer Institute. Norepinephrine Bitartrate. NCI Thesaurus. Code C48646.

A bitartrate salt of norepinephrine, a synthetic phenylethylamine that mimics the sympathomimetic actions of the endogenous norepinephrine. Norepinephrine bitartrate acts directly on the alpha- and beta-adrenergic receptors. Clinically, norepinephrine is used as a peripheral vasoconstrictor that causes constriction of arterial and venous beds via its alpha-adrenergic action. It is also used as a potent inotropic and chronotropic stimulator of the heart mediated through its beta-1 adrenergic action. 